\title{
AN APPRAISAL OF THE CONSTITUTIONAL AND REGULATORY MECHANISMS FOR THE APPOINTMENT OF JUDICIAL OFFICERS IN NIGERIA AND ASSOCIATED CHALLENGES
}

\author{
Musa Adamu Aliyu \\ School of Law, UUM COLGIS, \\ Universiti Utara Malaysia \\ E-mail: msaliyu1977@gmail.com \\ Nor Anita Abdullah \\ School of Law, UUM COLGIS, \\ Universiti Utara Malaysia \\ E-mail: noranita@uum.edu.my \\ Haslinda Muhd Anuar \\ School of Law, UUM COLGIS, \\ Universiti Utara Malaysia \\ E-mail: haslinda@uum.edu.my
}

Faculty of Law, Nigeria Police Academy, Wudil-Kano, Nigeria

Abstract: The institution to settle the dispute between individuals is a court of law manned by Judges. To nominate and appoint the judges are herculean tasks which involve processes to ensure only fit and proper persons occupy Judicial Offices. This article examined the constitutional and regulatory procedures for the appointment of Judicial Officers in Nigeria. The study identified the problems associated with the processes of the appointment of the Judicial Officers in Nigeria. The work adopted the socio-legal research method by using the qualitative approach. There is a dearth of literature in Nigeria on how the procedure for the appointment of Judicial Officers operates practically and the real problems associated with the operation of the procedural laws. To achieve the research objectives, a semi-structured interview was used. Three specialists in the Nigerian legal profession were interviewed to find out the actual issues on the ground. The study discovered that lobbying has been entrenched in the process of the appointment of Judicial Officers in Nigeria. The research further found that the powers of the Chief Justice of Nigeria to appoint the majority of 
members of the recommendation body threatens the independence of the Judiciary.

Abstrak: Pertelingkahan dalam masyarakat adalah sesuatu yang pasti; di mana tiada keraguan yang ia pasti akan berlaku. Untuk mencadang dan melantik hakim merupakan satu tugas yang agak berat yang mana melibatkan beberapa proses untuk memastikan hanya orang yang sesuai dan layak sahaja boleh memegang jawatan sebagai Pegawai Kehakiman. Penulisan ini akan mengkaji mengenai perlembagaan dan prosedur perundangandalam pelantikan Pegawai Kehakiman di Nigeria. Kajian akan mengenal pasti masalah yang terlibat dengan proses pelantikan Pegawai Kehakiman di Nigeria. Kajian ini menggunakan kaedah sosio-perundangan dengan menggunakan pendekatan kualitatif. Terdapat kekurangan dari segi sorotan karya di Nigeria berkenaan dengan prosedur pelantikan Pegawai Kehakiman yang dilaksanakan secara praktikal dan masalah sebenar yang seiring dengan pelaksanaan undang-undang secara prosedural. Untuk mecapai objektif penyelidikan, temubual secara semi-struktur digunakan. Tiga orang pakar di Nigeria dalam profesion undang-undang telah ditemubual untuk mencari isu sebenar yang berlaku di lapangan. Kajian mendapati bahawa lobi telah diamalkan dalam proses pelantikan Pegawai Kehakiman di Nigeria. Pengkaji selanjutnya mendapati bahawa kuasa Ketua Hakim Nigeria untuk melantik anggota majoriti badan yang dicadangkan; memberi ancaman kepada kebebasan Badan Kehakiman.

Kata Kunci: Keperlembagaan, Mekanisme Perundangan, Cabaran Berkaitan.

\section{INTRODUCTION}

In every civilized society, there are trained personnel appointed by the Government to adjudicate disputes based on facts and the law. ${ }^{1}$ The appointed adjudicators do not have an easy task; they constantly discharge the adjudicatory responsibility, which many people seek to avoid. ${ }^{2}$ Although there are other persons that are ready and willing

Jadesola O Akande, Introduction to the Constitution of the Federal Republic of

Nigeria 1999 (MIJ Publishers, 2000): 32.

2 Pannick, D. (1987). Judges. (Oxford: Oxford University Press, 1987), 1. 
to become judges, selection of the competent persons to occupy the exalted office has never been easy. At times many persons with the basic requirements apply to be considered for appointment to the limited number of vacancies. In considering the applicants, there are designed processes and procedures to be used in sifting the suitable persons to be appointed to the various Judicial Offices. But the bottom line is that when it comes to the appointment merit, integrity, professionalism and appropriate training are the watchwords. This article focused on the Constitutional and the regulatory mechanisms for the appointment of Judicial Officers in Nigeria. The work identified associated challenges with the processes of the appointment. In achieving the objectives of the research, the sociolegal research method was employed. The study found inconsistent provisions in the qualifications of the Judicial Officers in Nigeria. The requirement of sponsorship from serving Judicial Officers for candidates to Judicial Offices has entrenched the culture of lobbying. Other challenges discovered in the study include double membership in advisory and recommendation bodies by four Federal Judicial Officers and the wide powers given to the Chief Justice of Nigeria to control the National Judicial Council as a threat to the independence of the Judiciary in Nigeria.

\section{Theoretical framework}

Ferejohn defines judicial independence as "the freedom of judges from external and internal pressure in discharging judicial functions." "3 Oluyede, simply put judicial independence to mean "the independence of the judges to think freely and act freely according to the dictates of their conscience in line with the provisions of the law without any let or hindrance or fear of repercussion from any quarters whether from the Legislative, Executive, individual members of the public or even from the ghost of the individual judges past, present or future." 4

However, the meaning of judicial independence, according to Richardson, is a credible mechanism for the appointment of judges

3 John Ferejohn, "Dynamics of Judicial Independence: Independent Judges, Dependent Judiciary," http://www.usc.edu./dept/law/symposia/judicial/pdf/ ferejohn.pdf (accessed May 9, 2018)

4 Peter Oluyode, Peter Oluyode's Constitutional Law in Nigeria, (Ibadan: Evans Brothers Nigeria Publishers Ltd, 2001): 286 
coupled with the security of tenure, and financial autonomy protected by the law, to enable the judges to determine cases based on facts and law. In discharging their functions, the judges, are free from outside influence, the non- interference instills public confidence in the judiciary. ${ }^{5}$ The latter definition is flexible and has encapsulated the elements of judicial independence identified by the literature cited above. Furthermore, the definition has expanded the meaning by introducing the process of the appointment of judges.

Part of the definition of Richardson will be used in the current study given the fact that it recognizes a device for the appointment of judges as an integral part of the independence of the judiciary. What this article is seeking to show is that there are inherent challenges in the structured mechanisms for the appointment of judicial officers in Nigeria. The mechanisms for the appointment of judicial officers are part of the constitutional framework for judicial independence. The framework appears ineffective to insulate the judicial appointment from influence and pressure. In order to support the contention, the mechanisms for the appointment of judicial officers have been discussed.

\section{Classification of Judicial Officers}

There is nowhere in the Constitution that the phrase Judicial Officer has been defined. ${ }^{6}$ But Judicial Officers have been classified into Federal and State Judicial Officers. This classification has been made based on the persons empowered by the Constitution to appoint such Judicial Officers. Federal Judicial Officers are Judges of the Superior Court of Records, within the powers of the President of Nigeria to appoint. The Judicial Officers appointments saddled with the State Governors are called the State Judicial Officers. ${ }^{7}$

5 Kristy Richardson, "The Definition of Judicial Independence," 2015, http:// www.classic.austlii.edu.au (accessed May 11, 2018)

6 Muhammad, R.S. et al., "Misconduct by a Judicial Officer in Nigeria: An Analysis of its Scope," Ahmadu Bello University, Zaria Journal of Public and International Law 1, no. 7 (2015): 104; Ali, B.P, “The Appointment, Discipline and Removal of Judicial Officers: The Role of the National Judicial Council Under the 1999 Constitution As Amended," Ebonyi State University Law Journal, 6, no. 2 (2015): 230.

7 This classification is an innovation by the National Judicial Council, the highest recommending body for the appointment of Judicial Officers in Nigeria. The categorization had been provided in the Nominal Roll of Judicial Officers prepared by the Department of Planning, Research and Statistics, National Judicial Council. See "National Judicial Council Federal Judicial Officers Nominal 
Federal Judicial Officers consist of: the Chief Justice of Nigeria who is the Head of the Supreme Court; the President of the Court of Appeal who serves as the Head of the Court of Appeal. The other Heads of the Federal Courts are the Chief Judge of the Federal High Court, the President of the National Industrial Court, the Chief Judge of the High Court of the Federal Capital Territory, Abuja, the Grand Kadi of the Sharia Court of Appeal of the Federal Capital Territory, Abuja, and the President of the Customary Court of Appeal of the Federal Capital Territory, Abuja. ${ }^{8}$ The Justices, Judges, and Kadis under the leadership of the Heads of the Courts mentioned are also Federal Judicial Officers. Both the Heads of the Court and the other Federal Judicial Officers are appointed by the President of the Federal Republic of Nigeria. ${ }^{9}$

Furthermore, the Heads of the State Judicial Officers include the 36 State Chief Judges in the Federation, the Grand Kadis of the Sharia Court of Appeal of a State and the Presidents of the Customary Court of Appeal of a State. Other State Judicial Officers cover the State High Court Judges, the Kadis of the Sharia Court of Appeal of a State, and the Judges of the Customary Court of Appeal of a State. ${ }^{10}$

\section{Recommendation and Advisory Bodies for the Appointment of Judicial Officers}

No person can become a Judicial Officer in Nigeria without him being recommended by a recommendation body on the advice of the Federal and State advisory bodies as the case may be. It is the responsibility of the recommendation body to recommend candidates to the President or the State Governors depending on the judicial office. In other words, the recommendation body established by the Constitution, the National Judicial Council, (NJC) is the highest body to certify to the President or Governor,

Roll as on $27^{\text {th }}$ November, 2017". The other document titled: "National Judicial Council States Judicial Officers Nominal Roll as on $20^{\text {th }}$ June, 2017."

8 Paragraph 3(6) of the National Judicial Council Judicial Discipline Regulations 2017 listed the mentioned Judicial Officers as Heads of Court.

9 See sections: 231(1), 238(1), 250(1), 254B(1), 256(1), 261(1) of the Constitution (as amended).

10 See sections 271(1), 276(1) and 281(1) of the Constitution (as amended). 
suitable persons for appointment to the Judicial Offices. ${ }^{11}$ Below the NJC are three coordinate advisory bodies; two of the bodies are at the Federal level and the other body is at the State Level. The federal Judicial Service Commission, ${ }^{12}$ the Federal Capital Territory, and the Judicial Service Committee operate as an advisory body to the National Judicial Council when it comes to the appointment of the Federal and Federal Capital Territory Judicial Officers. Within the spheres of the appointment of the State Judicial Officers, is the responsibility of the State Judicial Service Commission to advise the National Judicial Council of suitable persons qualified to occupy the exalted office. ${ }^{13}$

\section{(a) National Judicial Council}

The National Judicial Council is comprised of the Chief Justice of Nigeria, as Chairman of the council, and the next most senior Justice of the Supreme Court as Deputy Chairman. ${ }^{14}$ Other council members consist of ten serving Judicial Officers (who are Heads of Court), and five retired Justices from among the Supreme Court or Court of Appeal, selected by the Chief Justice of Nigeria. ${ }^{15}$ Furthermore, there are five Members of the Nigerian Bar Association with at least 15 years post call; one of whom shall be a Senior Advocate of Nigeria, ${ }^{16}$ and non-legal practitioners, who in the opinion of the Chief Justice of Nigeria are of unquestionable integrity. ${ }^{17}$ One of the powers of the NJC is to recommend to the President and Governors persons

11 Sections 153(1)(i); 158(1) and Paragraph 21(a) of Part I to the Third Schedule of the Constitution (as amended).

12 Section 158 and Paragraph 12(a) of Part I to the Third Schedule of the Constitution (as amended).

13 Section 197(1)(c) and Paragraph 5 (6)(a) of Part II to the Third Schedule of the Constitution (as amended).

14 Paragraph 20(a) \& (b) of Part I of the Third Schedule of the Constitution (as amended).

15 Paragraph 20(c) - (h) of Part I to the Third Schedule of the Constitution (as amended).

16 Paragraph 20(i) of Part I of the Third Schedule of the Constitution (as amended). The position of a Senior Advocate of Nigeria's is the highest and a prestigious position a legal practitioner could attain in his career. The rank has privileges attached of to it. One such privilege is for the holder of the rank to sit at an inner bar in a court of law and to mention his cases before other legal practitioners. The rank is equivalent to the Queens Counsel in England.

17 Paragraph 20(j) of Part I of the Third Schedule of the Constitution (as amended). 
suitable for appointment to the Federal and the State Judicial Offices respectively. The names of the nominees to be considered for the appointments are forwarded or submitted in a list by the Federal Judicial Service Commission, the Judicial Service Committee of the Federal Capital Territory, Abuja, and the State Judicial Service Commission. ${ }^{18}$

\section{(b) Federal Judicial Service Commission}

The Federal Judicial Service Commission(FJSC) is a body established by the Constitution as a Federal Executive body, like the National Judicial Council. ${ }^{19}$ In the commission there are nine members; the Chairman of the commission is the Chief Justice of Nigeria. ${ }^{20}$ Eight other members in the composition of the commission which include three ex-officio members are the President of the Court of Appeal, ${ }^{21}$ the Attorney-General of the Federation, ${ }^{22}$ the Chief Judge of the Federal High Court, ${ }^{23}$ and the President of the National Industrial Court. ${ }^{24}$ The Nigerian Bar Association has two representatives in the commission, each of whom shall be a qualified legal practitioner of at least 15 years standing. ${ }^{25}$ Two non-lawyers are appointed by the President, and who in his opinion, are of unquestionable integrity. ${ }^{26}$ The Federal Judicial Service Commission is the sole body responsible for advising the National Judicial Council in nominating credible persons to be appointed to the Federal Judicial Offices. ${ }^{27}$ The Federal

18 Paragraph 21(a)(i),(ii), and (c) of Part I of the Third Schedule of the Constitution (as amended).

19 Section 153(1) of the Constitution (as amended).

20 Paragraph 12(a) of Part I of the Third Schedule of the Constitution (as amended).

21 Paragraph 12(b) of Part I of the Third Schedule of the Constitution (as amended).

22 Paragraph 12(c) of Part I of the Third Schedule of the Constitution (as amended).

23 Paragraph 12(d) of Part I of the Third Schedule of the Constitution (as amended).

${ }^{24}$ Paragraph 12(d) of Part I of the Third Schedule of the Constitution (as amended).

25 Paragraph 12(e) of Part I of the Third Schedule of the Constitution (as amended).

26 Paragraph 12(f) of Part I of the Third Schedule of the Constitution (as amended).

27 Paragraph 13(a) i-vib of Part I of the Third Schedule of the Constitution (as amended). 
Judicial Officers of the commission who advice the council with respect to their appointments are: "the Chief Justice of Nigeria, a Justice of the Supreme Court; the President of the Court of Appeal; a Justice of the Court of Appeal; the Chief Judge of the Federal High Court; a Judge of the Federal High Court; the President of the National Industrial Court, and the Chairman and members of the Code of Conduct Tribunal." ${ }^{28}$

\section{(c) State Judicial Service Commission}

The commission was created by section 197(1) (c) of the Constitution (amended). There are 36 states in Nigeria; ${ }^{29}$ each of the states has a commission. The composition of the commission includes the Chief Judge of the State, who shall be the Chairman..$^{30}$ After the Chairman there may be seven members of the commission depending where a state has both the Sharia Court of Appeal and the Customary Courts of Appeal. ${ }^{31}$ Among the members of the commission are ex-officio members. The officials are the Attorney-General of the State; ${ }^{32}$ the Grand Kadi of the Sharia Court of Appeal of the State; if any, ${ }^{33}$ and the President of the Customary Court of Appeal, if any. ${ }^{34}$ (It should be noted that the establishment of the Sharia Court of Appeal and the Customary Court of Appeal of a State are optional. It is within the powers of the State House of Assembly to create and establish either of the courts or all of the courts). ${ }^{35}$ There are two legal practitioners

28 Paragraph 13(a)-(vib) of Part I of the Third Schedule of the Constitution (as amended).

29 Section 3(1) of the Constitution (as amended).

30 Paragraph 5(a) of Part II of the Third Schedule of the Constitution (as amended).

31 From the Nominal Roll of State Judicial Officers, there are

32 Paragraph 5(b) of Part II to the Third Schedule of the Constitution (as amended).

33 Paragraph 5(c) of Part II to the Third Schedule of the Constitution (as amended).

34 Paragraph 5(d) of Part II to the Third Schedule of the Constitution (as amended).

35 There are five states with both the Sharia Court of Appeal and the Customary Court of Appeal The States are Kaduna, Kogi, Nassarawa, Plateau and Taraba. They are only 12 states with Sharia Court of Appeal. The states are Bauchi, Borno, Jigawa, Kano, Katsina, Kebbi, Kwara, Niger, Sokoto, Yobe and Zamfara. States with the Customary Court of Appeal are: Abia, Anambra, Bayelsa, Edo, Benue, Delta, Ebonyi, Enugu, Imo, Ondo, Osun, and Rivers. There are six states without either of the two courts. The States are Akwa-Ibom, 
in the composition of the State Judicial Service Commission; the lawyers must have qualified to practice as legal practitioners in Nigeria for at least a period of 10 years. ${ }^{36}$ Also in the structure, there are two non-legal practitioners, who in the opinion of the State Governor have unquestionable integrity. ${ }^{37}$

\section{(d) Judicial Service Committee of the Federal Capital Territory, Abuja}

The Federal Capital Territory of Nigeria is not a state. It is the capital of the Federation and the seat of the Government of the Federation. $^{38}$

The Judicial Service Committee for the Federal Capital Territory, Abuja, was established by section 304(1) of the Constitution (as amended). Members of the committee consist of the Chief Judge of the Federal Capital Territory, Abuja, as the Chairman. ${ }^{39}$ The Attorney-General of the Federation; the Grand Kadi of the Sharia Court of Appeal of the Federal Capital, Territory, Abuja; and the President of the Customary Court of Appeal of the Federal Capital Territory, Abuja, are ex-officio members..$^{40}$ The rest of the committee members are a legal practitioner who has been qualified to practice as a legal practitioner in Nigeria for a period of not less than twelve years; ${ }^{41}$ and one other person, not a legal practitioner but who, in the opinion of the President, is of unquestionable integrity. ${ }^{42}$

Cross River, Ekiti, Lagos, Ogun and Oyo. Source: National Judicial Council States Judicial Officers' Nominal Roll, as on $20^{\text {th }}$ June, 2017 compiled by the Planning, Research \& Statistics Department of the Council.

36 Paragraph 5 (e) of Part II of the Third Schedule of the Constitution (as amended).

37 Paragraph 5(f) of Part II of the Third Schedule of the Constitution (as amended).

38 Section 298 of the Constitution (as amended).

39 Paragraph 1(a) of Part III of the Third Schedule of the Constitution (as amended).

40 Paragraph 1(b)-(d) of Part III of the Third Schedule of the Constitution (as amended).

${ }^{41}$ Paragraph 1(e) of Part III of the Third Schedule of the Constitution (as amended).

42 Paragraph 1(f) of Part III of the Third Schedule of the Constitution (as amended). 
One of the functions of the Judicial Service Committee of the Federal Capital Territory, Abuja, is to advise the National Judicial Council on the appropriate persons for nomination to be appointed to the offices of: "the Chief Judge of the Federal Capital Territory, Abuja; a Judge of the High Court of the Federal Capital Territory, Abuja; the Grand Kadi of the Federal Capital Territory, Abuja; the President of the Customary Court of Appeal of the Federal Capital Territory, Abuja; a Kadi of the Sharia Court of Appeal of the Federal Capital Territory, Abuja; and a Judge of the Customary Court of Appeal of the Federal Capital Territory, Abuja." ${ }^{43}$

\section{Appointing and Confirmation Authorities of Judicial Officers in Nigeria}

The appointing authorities of the Judicial Officers are the President of the Federation and the 36 State Governors. The Chief Executives appoint the Judicial Officers based on the recommendation submitted to them by for the National Judicial Council on the advice of the Judicial Service Commissions and Committee. But for an appointment to the Justices of the Supreme Court and Heads of Court, there is the requirement of confirmation by the Senate for Justice of the Supreme Court and Heads of Federal Judicial Officers ${ }^{44}$, and State House of Assembly for State Heads of Court. ${ }^{45}$

Where the office of the Head of Court is vacant or the person occupying the office is unable to discharge the functions of that office, the constitution provides that the most senior Judicial Officer in that court shall be appointed as an Acting Head of Court to serve for a period of three months. The period of the Acting Head of the

Court could be extended on the recommendation of the National Judicial Council. ${ }^{46}$

\footnotetext{
43 Paragraph 1(2)(a)(i)-(vi) of the Constitution (as amended).

44 Sections 231(1),(2); 238(1);250(1);254B(1); 256(1);261(1); and 266(1) of the Constitution (as amended).

45 Sections 271(1); 276(1) and 281(1) of the Constitution (as amended).

46 Sections 231(4),(5); 238(4),(5); 250(4),(5); 254B(4),(5); 256(4),(5); 261(4),(5); $266(4),(5) ; 271(4),(5), 276(4),(5)$ and 281(4) \& (5) of the Constitution (as amended).
} 


\section{Qualifications for the Appointment of Judicial Officers}

The constitution outlines the general requirements that candidates aspiring for Judicial Offices must have before they could be recommended by the National Judicial Council to the President and State Governors, for the appointments to Judicial Offices. Persons suitable to occupy the offices of the Supreme Court Justices, Court of Justices, and High Court Judges (Federal and States) and Judges of the National Industrial Court must be qualified to practice as legal practitioners in Nigeria. The qualification must be held, prior to the appointment, by the aspirants for a period of at least 15 years for Justices of the Supreme Court; ${ }^{47} 12$ years for Court of Appeal Justices ${ }^{48}$ and 10 years for Judges of the High Courts ${ }^{49}$ and National Industrial court Judges. ${ }^{50}$ Apart from the Justices of the Court of Appeal, learned in customary and Islamic laws, and the Judges of the National Industrial Court, who must be conversant in the practice of customary law, Islamic Personal Law ${ }^{51}$ and labour related matters. All Judicial Officers mentioned above, need not be specialized in any area of law.

Other Judicial Officers which include the Kadis of the Sharia Courts of Appeal and the Customary Courts of Appeal, seeking to be appointed to such offices need not be legal practitioners. Attending, obtaining and holding a recognized qualification in Islamic law from an institution acceptable to the National Judicial Council is the prerequisite that a person who wishes to become a Kadi is required to have. The persons seeking for the appointments must also have held the qualification obtained, for a period of not less than 12 and 10 years for appointment to the office of Kadi of the Federal Capital Territory, Abuja, and the states respectively. In addition, such persons who aspire to become Kadis must have considerable experience in the practice of Islamic law, or they are distinguished scholars of Islamic law. ${ }^{52}$

\footnotetext{
Section 231(3) of the Constitution (as amended).

Section 238(3) of the Constitution (as amended).

Sections 250(3) and 271(3) of the Constitution (as amended).

Section 254B(3) of the Constitution (as amended).

Section 237(2),(b) of the Constitution (as amended).

Sections 261 (3) and 276(3) of the Constitution (as amended).
} 
Candidates for the office Kadis that are legal practitioners must obtain the qualification which applies to the High Court Judges. In other words, they must be qualified legal practitioners in Nigeria and have been so qualified for a period of not less than ten years. Apart from the foregoing qualifications, they must also have obtained a recognized qualification in Islamic Law from an institution approved by the National Judicial Council..$^{53}$

However, persons to be appointed as Judges of the Customary Courts of Appeal of the Federal Capital Territory, Abuja, and the states, like in the case of the Sharia Courts of Appeal, could either be legal practitioners or non-lawyers. The constitution empowers the National and State Houses of Assembly to make additional qualifications to be met by persons who aspire to become Judges of the Customary Courts of Appeal. Where legal practitioners, aspire for the appointment to the offices of the Judges of the Customary Court of Appeal of the Federal Capital Territory, Abuja, and the states, they must be qualified legal practitioners and have been so qualified for a period of not less than 10 years before seeking the offices. In addition to the professional qualification, the National Judicial Council must be of the opinion, that the legal practitioners have significant knowledge and experience in the practice of the customary law. ${ }^{54}$ A non-legal practitioner could also be appointed as the Judge of Customary Court of Appeal where the National Judicial Council opines that he has substantial knowledge and experience in the practice of the customary law. ${ }^{55}$

\section{Regulatory Mechanism for the Appointment of Judicial Officers}

The National Judicial Council in the process of appointing Judicial Officers had issued guidelines which guide the council in recommending to the president and the Governors suitable candidates for appointment as Judicial Officers. It was in 2004 that the written guidelines came into force. The guidelines were reviewed in 2014 by the National Judicial Council under the leadership of the former Chief Justice of Nigeria, Hon. Justice Aloma Mariam Mukhtar, Grand Commander of Niger, (GCON). ${ }^{56}$

Sections 261(2)(a) and 276(2)(a) of the Constitution (as amended).

54 Sections 266(3)(a) and 281(3)(a) of the Constitution (as amended).

55 Sections 266(3)(b) and 281(3)(b) of the Constitution (as amended).

56 The title of the guidelines is "NJC Revised Guidelines and Procedural Rules 
The Judicial Service Commissions and Committee, in advising the council when it comes to the appointment of the Judicial Officers, are mandatorily expected to comply with the guidelines. ${ }^{57}$ The guidelines have also provided steps to be followed by the National Judicial Council in recommending successful candidates to be appointed to the Judicial Offices. ${ }^{58}$

\section{Procedure for the Appointment of Judicial Officers in the NJC Revised Guidelines}

Where there is a vacancy on the bench, it is the responsibility of the Head of Court or Chairman of the State Judicial Service Commission to initiate the process of the appointment of suitable candidates to the Judicial Offices. With respect to the appointment of the State Judicial Officers, the Chief Judge of a state being the Chairman of the State Judicial Service Commission must notify the State Governor of the state concerned indicating the number of the Judicial Officers to be appointed. ${ }^{59}$ But in the case where a Federal Head of Court is to embark on the appointment of Federal Judicial Officers, notification of the exercise which must include the proposed number of the judges to be appointed shall be given to the Chief Justice of Nigeria who doubles as the Chairman of the Federal Judicial Service Commission. ${ }^{60}$ This latter rule applies to the appointment of the Judicial Officers of the Federal Capital Territory, Abuja. In other words, the Chief Judge of the Judicial Service Committee of the Federal Capital Territory, Abuja, shall give notice of embarking of the appointment process to the Chief Justice of Nigeria/Chairman of the Federal Judicial Service Commission. ${ }^{61}$ When the notice is sent to the State Governor, or Chief Justice of Nigeria, the Chairman of the Judicial Service Commission and the Committee, must ensure the copy of such notice has also been forwarded to the Secretary of the National Judicial Council. ${ }^{62}$ The Chairman of the State Judicial Service Commission must make sure that the Governor's reply to the intention to commence the process of the appointment is served on all the members of the Commission. ${ }^{63}$

2014," the guidelines came into force on the $3^{\text {rd }}$ November, 2014.

57 Rule 1 of the NJC Revised Guidelines, 2014

58 Rule 6 of the NJC Revised Guidelines, 2014

59 Rule 2(1) of the NJC Revised Guidelines, 2014.

60 Rule 2(a) of the NJC Revised Guidelines, 2014.

${ }_{61}$ Rule 2(b) of the NJC Revised Guidelines, 2014.

62 Rule 2(3) of the NJC Revised Guidelines, 2014.

63 Rule 2(6) of the NJC Revised Guidelines, 2014. 
However, the Secretary of the National Judicial Council on receipt of the notice of commencement of appointment shall advise the Chief Justice of Nigeria/Chairman of the National Judicial Council on the viability of the appointment. In giving the advice, the Secretary should take into consideration the relevant budgetary provision of the council for the year concerned. Based on the advice of the Secretary of the council, the Chairman of the National Judicial Council may approve the process to continue as proposed or with modification. It is also within the powers of the Chairman of the Council to refuse to grant approval of the process to continue. ${ }^{64}$ Whatever decision the Chairman of the National Judicial Council took will be communicated to the Head of Court or Chairman of the State Judicial Service Commission that initiated the process. ${ }^{65}$

Furthermore, in the event the Chairman of the National Judicial Council approving the proposal to commence the process of appointment of Judicial Officers, public notice shall be given for suitable candidates to express interest. The notice is to be sited on the website of the Judicial Service Commission/Committee concerned, notice boards of the Courts and the Nigerian Bar Association Branches. ${ }^{66}$ It is also the responsibility of the initiator of the appointment to formally call the Heads of Superior Courts of Record in the country and all Judicial Officers of the Courts concerned requesting the nomination of deserving persons for the proposed appointment. ${ }^{67}$ The formal notification should also be sent to the President of the Nigerian Bar Association in case of Federal appointments. But where the appointment is for State Judicial Officers, it is the Chairman of every Branch of the Association that must be called formally to nominate suitable candidates. The leaders of the Bar Association should also notify the appropriate candidates to come out with the notice of the expression of interest. ${ }^{68}$ However, in the case of appointment of Judicial Officers for the Court of Appeal and the Supreme Court, the Chief Justice of Nigeria and the President of the Court of Appeal, shall formally invite the Heads of Court, Justices of the Appellate Courts concerned and the President of the Nigerian Bar Association to nominate serving Judicial Officers and legal practitioners for appointments to the two Courts. ${ }^{69}$

64 Rule 2(4) of the NJC Revised Guidelines, 2014.

65 Rule 2(5) of the NJC Revised Guidelines, 2014.

66 Rule 3(i) of the NJC Revised Guidelines, 2014.

67 Rule 3(ii) of the NJC Revised Guidelines, 2014.

68 Rule 3(iii) of the NJC Revised Guidelines, 2014.

69 Rule 3(1)(b) of the NJC Revised Guidelines, 2014. 
Nomination of suitable candidates must be made in writing and the person nominating must clearly indicate that he is well acquainted with the nominee. In addition to that, the nominator must specifically declare that from his personal familiarity of the candidate, the latter has requisite qualities and qualification to become a judge set out by the law. ${ }^{70}$ After the closure of the nomination of candidates, the recommendation body concerned shall make a provisional list on the merits which shall include at least twice the number of Judicial Officers proposed to be appointed. The list shall be circulated among all retired and serving Judicial Officers of the court to which the appointment is to be made. Where the appointment is that of the Heads of Court, the list must be served on all retired and serving Heads of Court of the relevant Courts. In taking members of the Bar Association along, the Guidelines also requires the shortlist to be circulated to the Nigerian Bar Association's national headquarters, for Federal Judicial appointment and State Branches of the Association concerned with regard to the State Judicial Officers' appointment. The circulation of the list shall also be made to every Member of the Judicial Service Commission/Committee concerned. The objective of circulation of the shortlisted candidates to stakeholders is for them to make comments on the suitability or otherwise of the persons that made it to the list. ${ }^{71}$

The provisional list of the nominated candidates must be tabled before the Judicial Service Commission/Committee for approval. ${ }^{72}$

In approving the provisional list, the Judicial Service Commission/ Committee shall be guided, among other criteria, by the Federal Character or geographical spread of candidates without compromising merit, professional capability and skill of the nominees. The yardstick of assessing the nominees is to look at the area of their career. In the case of Judges, either of the inferior or superior courts, the quality of their decisions and judicial performance are to be looked at. Those shortlisted candidates from the Bar and the academics must demonstrate their competence through cases they handled before court of law. Candidates that are lawyers in the public service but on administrative cadre must display consistent sound and mature judgment. As for those in academics, they would be assessed

$70 \quad$ Rule 3(2) of the NJC Revised Guidelines, 2014.

71 Rule 3(4)(i)-(iv) of the NJC Revised Guidelines, 2014.

72 Rule 3(5) of the NJC Revised Guidelines, 2014. 
based on their credible record of teaching law, legal research in a reputable University and publication of legal works. In the case of appointment to the office of the Kadi of the Sharia Court of Appeal, understanding the Arabic language and grammar is mandatory. ${ }^{73}$ Furthermore, the nominated candidates must have good character and reputation. In addition to that, they must be honest and hardworking. ${ }^{74}$ The reputation of the nominee is ascertained through the Judicial Officers that nominated him, the comments made by the Nigerian Bar Association and the background check conducted on him by the Department of State Security Service. ${ }^{75}$

At the end of the deliberation of the Judicial Service Commission/ Committee, the decision reached with respect to the nomination and advice for the appointment of Judicial Officers, the duly adopted and authenticated resolution of the minutes of the meeting of the Commission/Committee shall be signed by the Chairman and the Secretary of the Commission/Committee. ${ }^{76}$ The follow up to that is a memorandum that shall be delivered to the Secretary of the National Judicial Council. The content of the memorandum must clearly indicate that the NJC Revised Guidelines 2014, have been complied with strictly and completely. ${ }^{77}$

After delivery of the memorandum to the Secretary of the National Judicial Council, such communication if scheduled on the agenda of the Council's meeting, the National Judicial Council may approve or decline to grant the request of the proposed process of the appointment to be kick-started. In approving the recommendation of the appointment of the nominees as Judicial Officers, the Council should regard the number of subsistent serving Judicial Officers of the court concerned. The workload of the court and the performance of the current Judicial Officers of the court concerned are also factors to take into consideration. ${ }^{78}$ After careful consideration of the factors, the Council may approve the recommendation or refuse it. Where the Council refused to recommend the appointment, it has the discretion to direct that no fresh advice shall be submitted by the Judicial Service Commission/Committee concerned until a particular

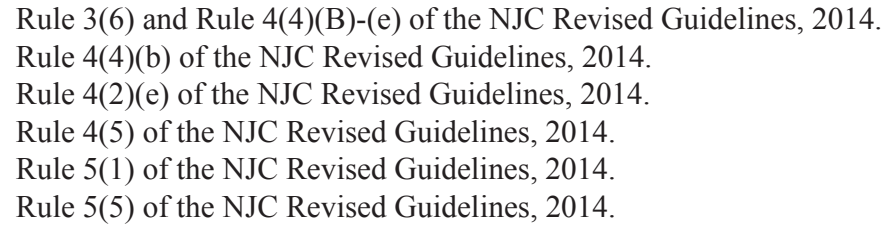


period of time. This strong interdiction could be taken in certain circumstances to include "absence of need, very low performance of the Judicial Officers of the Court concerned and low level of average judicial workload." 79

But where the Council approves to grant the recommendation, the shortlisted candidates would be subjected to an interview, the mode of which shall be determined by the Council. Only the candidates that successfully pass the interview would be recommended to the President or the State Governor concerned, as the case may be, for the appointment. ${ }^{80}$

\section{Challenges in the Process for the Appointment of Judicial Officers}

There are some difficulties associated with the process for the appointment of Judicial Officers.

\section{(i) Lack of uniformity in constitutional qualifications:}

The qualification for the appointment to Judicial Offices provided in the Constitution lacks consistency. The qualifications can be categorized into three. The first category requires academic and professional qualifications without practical experience. These people are legal practitioners aspiring to become Judicial Officers in the Supreme Court, the Court of Appeal, the High Court and the Federal High Court. The second group of people aspiring to become Judicial Officers must have academic and professional qualifications with acquired practical experience in specific areas of law. In this class, the nominees people aspiring to become Justices of the Court of Appeal should be learned in Islamic and customary laws. The same rule applies to the people who wish to become Kadis of the Sharia Court of Appeal and legal practitioners desirous of becoming Judges of the Customary Courts of Appeal. But in the case of a legal practitioner seeking to be a Judge of the Customary Court of Appeal, he is not required to show for how long he has been practising customary law. The last category of nominees is the group of aspirants that are not lawyers but want to become Judges of the Customary Courts of Appeal. These candidates require no academic

Ibid.

80 Rule 6(2)(3) and (4) of the NJC Revised Guidelines, 2014. 
and professional qualifications. All that the law requires is for the National Judicial Council to be of the opinion they have considerable knowledge of and experience in the practice of customary law. ${ }^{81}$

The dichotomies in providing constitutional qualifications show that in some offices, the requirements are stringent and watertight, while in others, discretion has been given to the National Judicial Council to determine the qualifications. This distinction sends a wrong signal that some Judicial Officers or nominees to such offices have more ability or preparedness to fulfill their judicial functions by virtue of the academic and professional qualifications they acquired coupled with the experience they had for a number of years before their appointment or being considered to become Judicial Officers.

In the case of the Judges of the Customary Courts of Appeal, there are no stated criteria by which knowledge and experience will be judged. Customary law in Nigeria is not codified and there are many of them. ${ }^{82}$ It might, therefore, be difficult to prove lack of knowledge of the customary law. ${ }^{83}$ Despite lacunae in stating the constitutional qualification, the Revised NJC Guidelines did not assist in providing guidance to the National Judicial Council when it came to considering an appointment to the office. But the same Guidelines added another qualification that a person who wishes to become the Kadi of the Sharia Court of Appeal, in addition to the stringent requirements, must have "knowledge of Arabic language and grammar."

Another constitutional inconsistency in stipulating the qualification of Judicial Officers is with regard to the Justices of the Supreme Court. The constitution provides that in the composition of the Justices of the Court of Appeal "... not less than three shall be learned in Islamic personal law, and not less than three shall be learned in Customary law..." 84 The Justices of the Court of Appeal that specialize in Islamic and customary laws are empowered by the constitution to

\footnotetext{
81 Sections 266(3)(b) and 281 (3)(b) of the Constitution (as amended).

82 Oba, A. A "Islamic Law As Customary Law: The Changing Perspective in Nigeria," The International and Comparative Law Quarterly 51 no. 4 (2002): 817; Aliyu, M.A et al., "Legal Mechanism for the Appointment of Judicial Officers in Nigeria," (paper presented at Seminar on Law (SOLAS, 2016), School of Law Universiti Utara Malaysia, December, 6, 2016).

83 Akande, J.O (2000). Introduction to the Constitutional Law of the Federal Republic of Nigeria (Lagos: MIJ Publishers Limited, 1999), 381 \& 393.

${ }_{84}$ Section 237(2)(b) of the Constitution (as amended).
} 
exclusively entertain appeals in Islamic and customary laws ${ }^{85}$ But where appeals of Islamic personal law and customary law, reach the Supreme Court, the Justices of the Apex Court constitutionally have authority to participate in all appeals, Islamic and customary laws inclusive, even though, the Justices might not be learned in the two areas of the law. This is a problem created by the constitution, for lacunae in not providing specific provisions for the appointment Justices learned in Islamic and customary laws to exclusively hear appeals on those two matters before the Apex Court. ${ }^{86}$

However, in stating the number of years a person who is not a legal practitioner must have held his obtained educational qualification, before his appointment as a Kadi, the constitution provides that such a person who is to become the Kadi of the Sharia Court of Appeal of the Federal Capital Territory, Abuja, must have "...held the qualification for a period of not less than twelve years.." ${ }^{\prime 87}$ But a person that is not a lawyer nominated for appointment as Kadi of the Sharia Court of Appeal of a State, must have held his educational qualification "...for a period of not less than ten years.." prior to his nomination. ${ }^{88}$ The question is why should constitutional provisions applicable to persons who aspire to occupy the position of similar status, differ in terms of the number of years both persons must acquire before appointing them? There is no plausible answer to the question raised!

\section{(ii) Lobbying to secure Judicial appointment}

Lobbying for judicial appointment by legal practitioners and nonlawyers is one area that has been bothering stakeholders in Nigeria. This problem has been recalcitrant in the country. The NJC Revised

85 Section 247(1)(a) and (b) of the Constitution (as amended).

86 There are instances at the Supreme Court where Justices that are not learned in Islamic Law or Customary law had an opportunity to deliver judgments in those areas. For example, the case of Rabiu v. Amadu (2012) LPELR - 7850 none of the Justices that participated in an appeal over paternity of a child under Islamic law was learned in Islamic law. The case of Opobiyi \& Anor v. Muniru (2011) LPELR - 8232 SC was an appeal on inheritance under Islamic law yet all the Justices that sat in the appeal were not learned in Islamic law. In this appeal, the Justice of the Supreme Court set aside the decision of the Court of Appeal Justices learned in Islamic personal law. In customary appeals, Justices of the Supreme Court that delivered decisions in Ukeje v Ukeje (2014) LPELR - 22724 SC and Anekwe \& Anor v. Anekwe (2014) LPELR - 22697 were not learned in customary law.

87 Section 261(3)(b) of the Constitution (as amended).

88 Section 276(3)(b) of the Constitution (as amended). 
Guidelines, 2014, made "canvassing or lobbying for the appointment directly or indirectly in any form and/or through any persons or persons, such as but not limited to, politicians, traditional rulers, public officers or other Judicial Officers.." a ground for the disqualification of a candidate. ${ }^{89}$ The foregoing provision of the guidelines is a clear case of the admission of the problem in Nigeria from the horses' mouth. The late Justice Niki Tobi (of blessed memory), a retired Justice of the Supreme Court and also a former Deputy Chief Justice of Nigeria, had in 1999, at the All Judges' Conference of Nigeria lamented how some persons seeking for Judicial appointments go about lobbying for Judicial appointments shamelessly. ${ }^{90}$ Recently, a former Chief Justice of Nigeria, Hon. Justice Aloma Mukhtar, termed the lobbying for judicial appointment as a rising "culture" that weakens or devalues the Nigerian Judiciary because it helps in the recruitment of incompetent personnel. ${ }^{91}$

The problem of the lobbying is that it has been opined that it is linked to the requirement that persons seeking Judicial Offices must be sponsored by serving Judicial Officers or the leadership of the Nigerian Bar Association at the national or the branches level as the case may be. According to a former Chairman of the Nigerian Bar Association, Kano Branch, and also a one-time Vice President of the Nigerian Bar Association, most of the time candidates had to lobby to be nominated by the Judicial Officers or the Chairmen of their branches of the Nigerian Bar Association. If the candidates do not lobby, they would not be considered for the appointment. The former official of the Nigerian Bar Association went further to show that, based on his experience, the Judicial Officers speak with one voice when it comes to the nomination for Judicial Office: "Even if they know you and you happen to be on the other side you might not get the recommendation and my experience with most of the judges, they speak with one voice. They will say $\mathrm{x}$ don't touch him and $\mathrm{x}$ will go they will not touch anyone. That is one of the biggest problems we have." ${ }^{92}$

\footnotetext{
$89 \quad$ Rule 4 (4)(ii)(a) of the NJC Revised Guidelines, 2014.

90 Aliyu, M. A. (2015). An appraisal of the procedure for appointment and removal of Judicial Officers in Nigeria. Nigeria Police Academy Law Journal ( Vol. 1., No. 2), 303.

91 Adesomoju, A. (2018). How lobbying, godfatherism weaken Nigerian Judiciary - Ex-CJN Mukhtar. The Punch Nigeria, https://www.punch.com (accessed March 11, 2018).

92 Interview conducted with Ibrahim Aliyu Nassarawa, former National Vice President of the Nigerian Bar Association at his law firm office, Kano on $26^{\text {th }}$ September, 2017.
} 


\section{(iii) Duplication of membership in the recommendation bodies}

Another problem with the process of appointment of Judicial Officers is that some members of the recommendation bodies do serve in more than one recommendation body. In the composition of the National Judicial Council and the Federal Judicial Service Commission, there are certain Federal Judicial Officers that are serving in both bodies. The Judicial Officers are the Chief Justice of Nigeria, the President of the Court of Appeal, the Chief Judge of the Federal High Court and the President of the National Industrial

Court. The repetition of the Judicial Officers to serve in the two bodies has a tremendous impact on the transparency of the process of the appointment of Judicial Officers in Nigeria. All the four Judicial Officers mentioned are Heads of Court. Based on the NJC Revised Guidelines, it is their duty to compile and shortlist the names of the prospective Judicial Officers of their courts. After they conclude the shortlisting, they should forward the names to the Federal Judicial Service Commission.

At the commission, the four Judicial Officers who are ex-officio members, they would participate in the deliberations over the names submitted by any of them, with the four of them in attendance. At the end of the meeting, a decision on suitable candidates would be taken, and forwarded to the National Judicial Council. At the National Judicial Council, the recommendation of the persons to be appointed to Judicial Offices, would be finalized, and the Four Judicial Officers would also partake in the meeting.

According to the former Vice President of the Nigerian Bar Association, allowing a Judicial Officer to serve in an advisory and recommendation bodies simultaneously, gives the Judicial Officer an undue advantage to cast two votes over one issue. In other words, he is allowed to have two bites over an issue. A one-time retired Judicial Officer described the multiple memberships in the two bodies as being contrary to the democratic principle of fairness: "I don't think it is fair;you can't be a member of the FJSC and NJC, and democratically it should not be so. It shouldn't be so in my own view. It should be another person because you will try to defend whatever you do. So I feel try 
to improve on that, separate the membership, if you are a member of this (body) you are a member of that body; one body only." 93

Another person interviewed, who is from the academics, ${ }^{94}$ criticizes the dual membership of the Chief Justice of Nigeria in the composition of the National Judicial Council and the Federal Judicial Service Commission. The Chief Justice of Nigeria, being the Chairman of the Federal Judicial Service Commission, and the National Judicial Council, where he appoints the majority members of the council, it would be difficult for the decision of the Chief Justice of Nigeria to be rejected. The dual membership inhibits excellence in the nomination of candidates: "It is duplication to allow one person to serve in more than one recommendation body. It is not helping matters and not emphasizing quality. I think the earlier we minimize dual and triple roles across the appointing bodies the better. Now tell me (the CJN) at the Federal Judicial Service Commission he sits and refuses. His votes or view is that Musa should not be appointed but the overwhelming majority voted for Musa, sent to the NJC and he is the Chairman what happens to the fate of Musa? In view of the 19 out of the 24 he has. I think the CJN should be left at the final, apex NJC. Other people should be given, you can put the President of the Court of Appeal for instance to be the Head of the Federal Judicial Service Commission. At least you are now giving transparent, I mean you cannot decide somebody's fate negatively and then come and decided it positively later. So this is my view." ${ }^{95}$

\section{(iv) Powers of the Chief Justice of Nigeria to appoint majority members of the National Judicial Council}

The power given to the Chief Justice of Nigeria to select and appoint 19 out of 23 members of the National Judicial Council is a threat to the Independence of the Judiciary. Constitutional donation of such power to one individual is not ideal. The Chief Justice of Nigeria, being human, might likely abuse the power. It is probable for the Chief Justice of Nigeria to appoint individuals he is more at ease

93 Interview with Honourable Justice Wada Abubakar Rano, a retired High Court Judge of Kano State High Court and current Chairman of the Kano State Law Reform Commission, on $11^{\text {th }}$ October 2017. The interview was conducted at the office of the Chairman, Kano State Law Reform Commission.

94 Dr. Dahiru Usman Jafaru, Lecturer, Department of Public Law, Faculty of Law, Bayero University, Kano, Nigeria.

95 The interview was conducted at his office, in the Department of Public Law, Faculty of Law, Bayero University, Kano, on $6^{\text {th }}$ September 2017 
with in the council. The appointed council members may likely dance to the tune of the Chief Justice of Nigeria even for the sake of a renewal of the exalted position. All the persons interviewed are of the opinion that the Chief Justice of Nigeria has absolute control of the National Judicial Council through his power of appointment, and the appointees of the Chief Justice of Nigeria "hardly turn their backs against him."

\section{CONCLUSION}

There is no doubt the appointment of Judicial Officers in Nigeria, like anywhere in the world, is paramount. The constitutional and regulatory mechanisms for the appointment of Judicial Officers need to be reviewed to tackle the challenges identified. It is the recommendation of this work that the constitution should be amended to make provisions in the constitution for the appointment of Judicial Officers consistent. The jurisdiction of the Supreme Court to hear appeals on Islamic and Customary laws should be abrogated. It is also part of the recommendation that the powers of the Chief Justice to appoint members of the National Judicial Council should be limited to the appointment of retired Judicial Officers. Finally, no person shall serve in dual capacities in the recommendation or advisory bodies.

\section{BIBLIOGRAPHY}

Adesomoju, A. (2018). How lobbying, godfatherism weakens Nigerian Judiciary - Ex-CJN Mukhtar. The Punch Nigeria. Retrieved from https://www.punch.com (accessed March 11, 2018).

Akande, J. O. (2000). Introduction to the Constitutional Law of the Federal Republic of Nigeria. Lagos: MIJ Publishers Limited, 1999.

Ali, B. P. (2015). The appointment, discipline and removal of Judicial Officers: The role of the National Judicial Council under the 1999 Constitution as amended, Ebonyi State University Law Journal, 6(2), 230.

Aliyu, M. A. (2015). An appraisal of the procedure for appointment and removal of Judicial Officers in Nigeria. Nigeria Police Academy Law Journal, 1(2), 303. 
Dahiru Usman Jafaru, Lecturer, Department of Public Law, Faculty of Law, Bayero University, Kano, Nigeria (interviewed on 6 September 2017).

Ibrahim Aliyu Nassarawa, former National Vice President of the Nigerian Bar Association (NB.A.) (interviewed on 26 September 2017).

Kristy Richardson. (2015). A definition of judicial independence. Retrieved from http://www.classic.austlii.edu.au

Jadesola O. Akande. (2000). Introduction to the Constitution of the Federal Republic of Nigeria 1999. MIJ Publishers): 32.

John Ferejohn. Dynamics of judicial Independence: independent judges, dependent judiciary, http://www.usc.edu./dept/law/ symposia/judicial/pdf/ferejohn.pdf

Judith Resnik (2005). Judicial selection and democratic theory: Demand, supply, and life tenure, Cardozo Law Review, 26(2), 579-658

Musa Adamu Aliyu, Nor Anita Abdullah \& Haslinda Muhd Anuar. (2016). Legal mechanism for the appointment of judicial officers in Nigeria Paper presented at the Seminar on Law (SOLAS, 2016). School of Law Universiti Utara Malaysia, Sintok, 2016.

Muhammad, R.S et al. (2015). Misconduct by a judicial officer in Nigeria: An analysis of its scope, Ahmadu Bello University, Zaria Journal of Public and International Law, 1, (7), 104.

Oba, A. A. (2002). Islamic law as customary law: The changing perspective in Nigeria, The International and Comparative Law Quarterly 51 no. 4: 817.

Pannick, D. (1987). Judges. Oxford: Oxford University Press.

Peter Oluyode. (2001). Peter Oluyode's constitutional law in Nigeria, (Ibadan: Evans Brothers Nigeria Publishers Ltd,: 286.

Sarkar Ali Akkas. (2004).Appointment of judges: A key issue of judicial independence, Bond Law Review, 16 (2), 768.

Wada Abubakar Umar, Retired High Court Judge of Kano State and Current Chairman of the Kano State Law Reform Commission (interviewed on 11 October 2017).

\section{Statutes}

Constitution of the Federal Republic of Nigeria, 1999 (as amended).

NJC Revised Guidelines, 2014. 